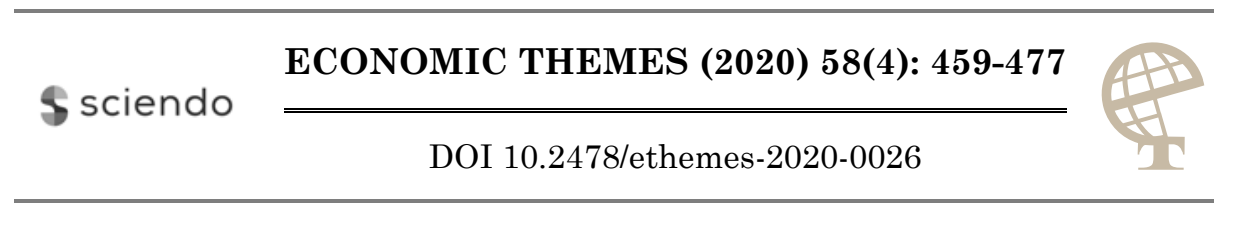

\title{
A REVIEW OF ECONOMIC AND ENVIRONMENT INDICATORS AND ENERGY EFFICIENCY: EVIDENCE FROM THE EU AND SERBIA
}

\author{
Sandra Jednak \\ University of Belgrade, Faculty of Organizational Sciences, Serbia \\ $\square$ sandra.jednak@fon.bg.ac.rs \\ Jelena Minović \\ Institute of Economic Sciences, Serbia \\ $\bowtie$ jelena.minovic@ien.bg.ac.rs \\ Dragana Kragulj \\ University of Belgrade, Faculty of Organizational Sciences, Serbia \\ $\bowtie$ dragana.kragulj@fon.bg.ac.rs
}

UDC

502.171:620.9

(4-672EU+497.11)

Original scientific paper

Received: 31.05.2020 Accepted: 29.09.2020

\begin{abstract}
Energy is a globally important factor of production - the growth of population and income increase energy consumption, so there is an urge to decrease it. However, there are different ways to reduce energy consumption, and one of them is energy efficiency. The aim of the paper is to give a theoretical review of energy efficiency and its benefits. The purpose of the paper is the analysis of economic and environmental indicators and energy efficiency in EU27 (after 2020) and Serbia. The trends of energy efficiency, GDP per capita and GHG emission are shown for the observed countries. The European and Serbian policies and targets for energy efficiency are presented and also the level these countries have reached the set targets. In order to see the relationship between energy efficiency, GDP per capita and GHG emission, the correlation among all variables is applied. The results show that energy efficiency is higher in EU27 than in Serbia. Even though Serbia had energy efficiency increase during the observed period (1995-2018), it lags behind the EU27. However, there is a positive correlation between energy efficiency and GDP and GHG emission in both EU27 and Serbia.
\end{abstract}

Keywords: energy efficiency, GDP, energy, CO2 emission, European Union, Serbia

JEL classification: O13, O49, Q43 


\section{Introduction}

Energy is one of the inputs in achieving economic growth. As population and industrialisation are growing, the energy demand and consumption and environmental pollution are also rising. Obtaining sustainable development and bringing down energy consumption, energy demand, and greenhouse gases (GHG) emission are contemporary and ongoing issues. There are theories that capital, labour and technology are factors of production. In energy economics, energy is taken as the only factor of production due to assessment energy efficiency (Zweifel, Praktiknjo \& Erdmann, 2017).

Energy efficiency is the efficient use of energy, and it can be defined from different aspects (technical and economic sides). It can be applied at different levels from households through sectors, buildings, communities, energy systems to national economy. Promoting energy efficiency can obtain economic, environmental and social benefits. Some of many benefits are: enhanced environment, economic development and sustainability, a decrease of energy demand, energy consumption, and energy imports dependency, the contribution of energy security, better health and well-being, etc. (IEA, 2019; Ryan \& Campbell, 2012; Kerr, Gouldson \& Barrett, 2017; Rosenow \& Bayer, 2017; Fawcett \& Killip, 2019). Besides benefits, energy efficiency improvement can also have negative impacts, such as the rebound effects and other disadvantages like economic barriers, awareness and consumer behaviour, not cost-effective investments (Gillingham, Rapson, \& Wagner, 2016; Trianni, Cagno\& Farné, 2016; Safarzadeh \& Rasti-Barzoki, 2019).

Since the oil crisis in 1970s, energy efficiency has been present in global and national strategies, policies, directives and regulations. Today, it is an issue that is incorporated in energy policy, law carbon energy policy or the policy of energy efficiency (Tracking Report, 2019; Malinauskaite, Jouhara, Ahmad, Milani, Montorsi, \& Venturelli, 2019). Each country should implement policy in line with its economic development and opportunities, but also with the sustainable economic development goals and global policy.

The focus of the paper is on the analysis of energy efficiency in EU27 and Serbia. The paper aims to show the benefits of energy efficiency and relationships between the selected economic and environmental indicators, and energy efficiency in observed countries. Furthermore, a short review of economic and environmental benefits of energy efficiency will be given. According to IEA (2019) economic benefits are the following: macroeconomic impact, industrial productivity, health and well-being, employment, disposable income, public budget, asset values, poverty alleviation, while environmental and energy benefits are: GHG emission, energy security, energy saving. However, the purpose of the paper is to show the benefits and relationship between energy efficiency and the selected indicators: gross domestic product - GDP (economic indicator) and $\mathrm{GHG} / \mathrm{CO}_{2}$ emission (environment indicator). 
In the paper, it is presented a theoretical review of energy efficiency in the observed countries and correlations of the selected indictors. The results show that energy efficiency is higher in EU27 than in Serbia. Although Serbia had energy efficiency increase during the observed period (1995-2018), it lags behind EU27. Energy efficiency varies among EU27 due to economic activities, consumer behaviour and the use of resources. It is higher in advanced member countries than in member countries from Eastern Europe. EU27 is becoming closer to obtain the set EU strategy 2030 targets than Serbia. Serbia has to do more to improve energy efficiency, in order to reach the set targets. There is a positive correlation between energy efficiency and GDP and GHG emission.

The structure of the paper is as follows. After the introduction, the second section offers a review of energy efficiency and trend in EU27 and Serbia, followed by the section about strategy and set targets. The fourth section presents economic and environmental benefits of energy efficiency. The fifth section shows the relationship between energy efficiency and GDP, and $\mathrm{CO}_{2}$ emission, followed by the results and discussion. The final chapter gives the concluding remarks.

\section{Trends of energy efficiency in EU27 and Serbia}

According to the definition of efficiency, energy efficiency presents the amount of energy output that can be produced with a given energy input, or reduction of the amount of energy (input) for the production of material goods and services (output). According to the EU Energy Efficiency Directive (European Parliament, 2015), it is the ratio of the output of performance, goods, services or energy and energy input. Various factors affect energy efficiency, including: technological (in terms of energy-using equipment), economic and financial (in terms of income and energy prices), institutional (in terms of infrastructure, property rights, etc.) and cultural (attitude, behaviours, etc.) (Nagesha \& Subrahmanya, 2006). Energy efficiency can be enhanced by better resource management or replacing the devices with unfavourable energy ratings, but investment has to pay off and to outweigh the costs (Zweifel, Praktiknjo \& Erdmann, 2017).

Energy efficiency is measured as monetary (energy per unit of product in euro) and physical (tons of coal per ton of steel) indictors like energy intensity, the efficiency of the overall energy system, net energy, energy use index (EUI), ODEYSSEE-MURE composite indicator, and others. Over time, various authors have tried to find even more appropriate measure for energy efficiency and its benefits. Energy intensity, an economic-wide measure, is applied in various studies concerning the EU and other countries. Energy intensity is measured in terms of primary energy consumption and GDP. It shows how much energy is needed to produce a unit of GDP. It is reciprocal to energy efficiency of a country's economy. The higher value of energy intensity shows the higher cost of converting energy into GDP, i.e. there is low energy efficiency. The lower value of energy 
intensity shows higher energy efficiency. Indicator Energy intensity of GDP in chain-linked volumes (2010), presented units in kilograms of oil equivalent (KGOE) per thousand euro is taken from Eurostat.

Due to economic structure, level of industrialisation, energy mix and applied energy efficiency measurements, there is a difference in energy intensity. Petrović, Filipović \& Radovanović (2018) determined the factors that make energy intensity in the EU countries. Gross fixed capital formation and gross industrial value added have a positive influence on energy intensity. In contrast, real per capita gross domestic product and oil products retail price have a negative influence. Goldemberg (2020) evaluates the energy intensities of developing countries. According to Goldemberg (2020), world energy intensity declines due to the change in the world's energy mix, the raise in the efficiency of conversion of the heat content of fossil fuels into mechanical energy, the use of electricity, technological "leapfrogging" and environmental issues arising from the coal use. Mussi (2020) explores convergence in energy intensity in the European Union. The results show that convergence is present in the first year's membership consideration, and a slowdown in the following years. Cornillie \& Fankhauser, (2004) identify the energy intensity decline in transition countries, but the decline has been uneven among the observed countries. Sadorsky (2013) explores energy intensity in developing countries. The author finds that income increases energy intensity, and the impact of urbanisation is mixed.

Energy efficiency should be enhanced by production, using energy efficiently to final consumption and consuming less. Energy efficiency measures are focused on the sectors that can obtain energy efficiency, such as buildings, transport and services. Figure 1 shows the energy intensity in EU27 and Serbia for the period 1995-2018. Energy intensity is calculated as a ratio of gross inland energy consumption (thousands of tons of oil equivalent) and real GDP (2010 in chainlinked volumes, in thousands of euros) (Eurostat). The energy intensity in Serbia is much higher than in EU27. For example, in 2018, energy intensity in EU27 was 123.30, while in Serbia it was 428.60 (Eurostat, 2019). During 1995-2018, Serbia and EU27 countries had a decrease in energy intensity. In the period between 1995 and 2018, the EU's energy intensity dropped by 31\%, while Serbian energy intensity decreased by $55 \%$. Energy intensity in Serbia is four to five times higher than in the advanced EU countries. It means that Serbia has higher energy consumption than EU countries in order to produce the same output. Bulgaria, the Czech Republic, Hungary, Latvia, Lithuania, Malta, Poland, Romania, Slovakia and Slovenia all have high energy intensity. In 2018, Bulgaria (414.36) had a relative value of energy intensity similar to Serbia. Those countries (especially Romania, Slovakia and Lithuania) recorded energy intensity decline due to economic structure changes. Even so, they still stay behind the advanced EU member countries. 
Figure 1 Energy intensity in EU27 and Serbia, 1995-2018

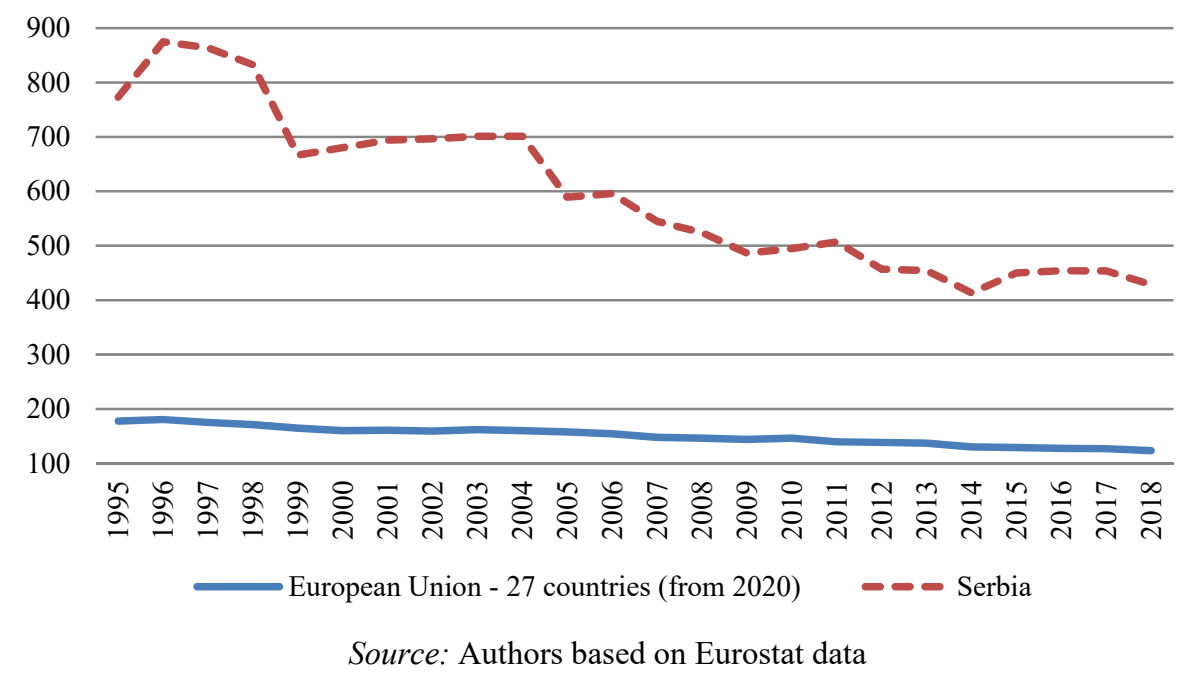

The result of a low level of energy intensity is due to the EU and national directives and initiatives. For example, the EU launch initiatives like promoting cogeneration, the performance of buildings and energy labelling for a domestic appliance. According to EEA (2019), over this period, the energy efficiency of end-use sectors (final consumers) was improved by $30 \%$ at an average rate of $1.4 \%$ per year. This energy efficiency enhancement was driven by all sectors, but mostly by industry and household sectors and technological innovation. Until 2005, the EU had a relatively high economic growth and modest increase of gross inland energy consumption. From 2005, economic growth and gross inland energy consumption growth were lower due to the economic crisis. However, since 2014, energy consumption started to increase due to energy efficiency improvement.

In Serbia, the promotion of energy efficient appliances in households, new energy efficiency in building sector, certification in households, public and commercial sectors, modernisation in transport, promotion of energy efficiency in industry, and introduction of energy management system had a significant impact on the decrease of energy intensity. Even though Serbia implements measures, the high share of coal in production and industry, energy-intensive industries, a high share of households in final energy consumption, and unrealistic price of energy and energy products have a disincentive effect on activities to increase energy efficiency.

There are various factors that can influence energy consumption. Krstić et al. (2019) review empirical methods to determine the influence of factors that have impact on consumption. Economic structure, energy mix and economic growth they all affect energy consumption. If energy-intensive countries increase production, they boost demand for primary energy fuel. This means that income 
rise will push up energy consumption. Energy efficiency leads to a decrease in energy consumption. According to Sorrell (2015), the correlation between raised wealth and raised energy consumption is very strong. Also, the paper shows the impact of limitations and contents of the policies on reduction of energy demand. This kind of relationships can be seen in energy consumption in the observed countries (EU27 and Serbia). Figures $2 a$ and $2 b$ show primary energy consumption in the observed countries. Energy consumption is much higher in EU27 than in Serbia. Energy consumption depends on population and income.

Figure 2a. Primary energy consumption in EU27, 1995-2018, millions of tonnes of oil equivalent (Mtoe)

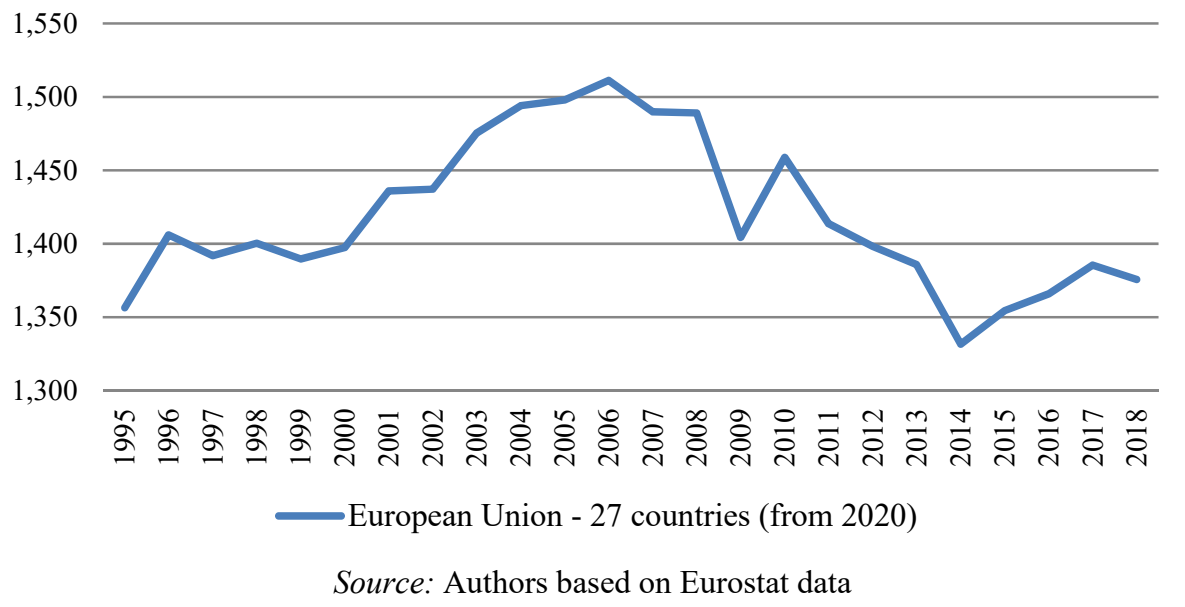

Figure 2b. Primary energy consumption in Serbia, 1995-2018, millions of tonnes of oil equivalent (Mtoe)

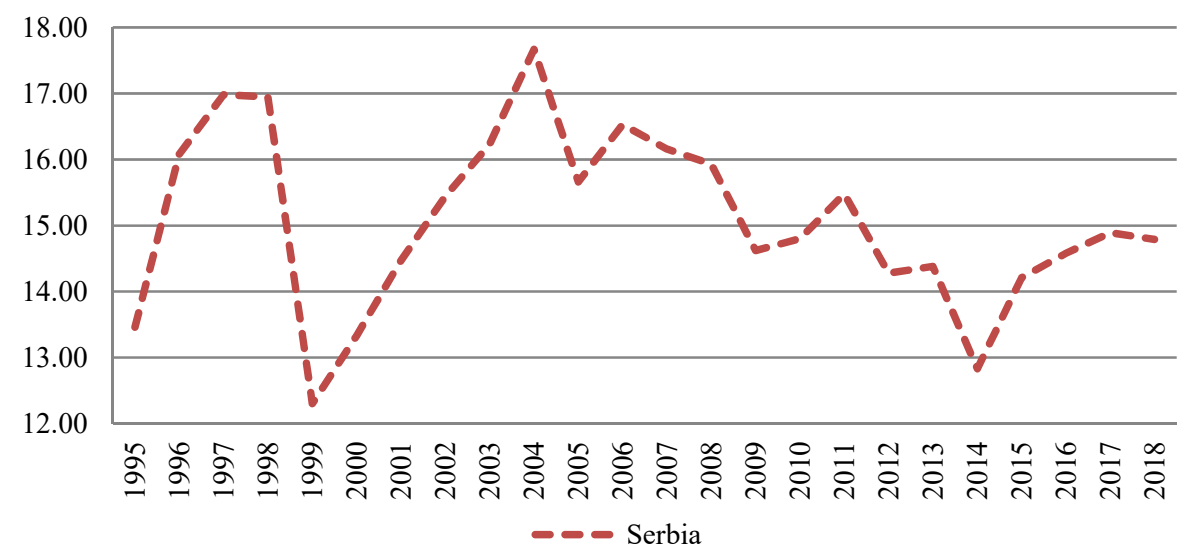

Source: Authors based on Eurostat data 
From 1995 till 2007, there was a rise in primary energy consumption, and then the slope of the energy consumption in EU27. The peak was in 2006 (1511.19 Mtoe), and the lowest level in 2014 (1331.63 Mtoe). In Serbia, from 1995 there was a rise in energy consumption, then a slope in 1999. With economic reform that started in 2000, energy consumption started growing. In 2004 it reached value of 17.6 Mtoe. From 2005 till 2018 there was a relatively steady energy consumption. The energy consumption decreases during economic crisis. The lowest energy consumption was in 2014 (12.83 Mtoe). After that, energy consumption increased. In 2018, energy consumption in EU27 was 1375.66 Mtoe and in Serbia it was 14.79 Mtoe.

The energy mix influences energy efficiency, i.e. energy intensity. Energy intensity decreases mainly due to fuel substitution apart from coal (Reddy \& Ray, 2010; Goldemberg , 2020). Table 1 shows EU27 and Serbia energy mix.

Table 1. EU 27 and Serbia energy mix, 1995, 2000, 2010 and 2018 (\%)

\begin{tabular}{|c|c|c|c|c|c|c|c|}
\hline & & EU27 & Serbia & & & EU27 & Serbia \\
\hline \multirow{5}{*}{ Solid fossil fuels } & 1995 & 20.95 & 64.84 & \multirow{5}{*}{$\begin{array}{l}\text { Renewables and } \\
\text { biofuels }\end{array}$} & 1995 & 5.58 & 11.64 \\
\hline & 2000 & 18.14 & 63.7 & & 2000 & 6.26 & 12.14 \\
\hline & 2010 & 15.26 & 49.67 & & 2010 & 10.81 & 13.17 \\
\hline & 2018 & 13.81 & 48.56 & & 2018 & 14.59 & 12.99 \\
\hline & $\Delta 2018-1995$ & -7.14 & -16.28 & & $\Delta$ 2018-1995 & +9.01 & +1.35 \\
\hline \multirow{5}{*}{ Natural gas } & 1995 & 18.23 & 9.9 & \multirow{5}{*}{ Nuclear heat } & 1995 & 13.78 & 0 \\
\hline & 2000 & 20.06 & 11.3 & & 2000 & 14.43 & 0 \\
\hline & 2010 & 22.86 & 11.87 & & 2010 & 13.74 & 0 \\
\hline & 2018 & 21.32 & 13.71 & & 2018 & 12.86 & 0 \\
\hline & $\Delta 2018-1995$ & +3.09 & +3.81 & & $\Delta$ 2018-1995 & -0.92 & 0 \\
\hline \multirow{5}{*}{$\begin{array}{l}\text { Oil and petroleum } \\
\text { products (excluding } \\
\text { biofuel portion) }\end{array}$} & 1995 & 40.63 & 13.87 & & & & \\
\hline & 2000 & 40.31 & 10.95 & & & & \\
\hline & 2010 & 36.45 & 25.39 & & & & \\
\hline & 2018 & 35.95 & 24.66 & & & & \\
\hline & $\Delta 2018-1995$ & -4.68 & +10.79 & & & & \\
\hline
\end{tabular}

Note: $\Delta$ 2018-1995: the change that occurred in the period 2018-1995

\section{Source: Authors based on Eurostat data}

In 2018, the EU's energy mix was made up of the following resources: solid fossil fuels $(13.81 \%)$, natural gas $(21.32 \%)$, oil and petroleum products (including crude oil) (36\%), renewable energy and biofuels (14.59\%) and nuclear energy $(12.86 \%)$. The resources such as oil shale and non-renewable waste have not been presented due to a small share - less than $1 \%$. The shares of various energy sources in the total energy differ among the EU countries. The energy mix in Serbia was made up of: solid fossil fuels $(48.56 \%)$, natural gas (13.71\%), oil and petroleum products (including crude oil) (24.66\%), renewable energy and biofuels (12.99\%) 
and nuclear energy (0\%). If we compare 1995 and 2018, the contribution of solid fossil fuels (coal) was reduced by $7.14 \%$ in EU27 and by $16.28 \%$ in Serbia. At the same time, the share of renewables and biofuels rose by $9.01 \%$ in EU27 and by $1.35 \%$ in Serbia. The change in energy mix structure shows that the observed countries apply the measurement of energy efficiency due to the increase of renewable energy resources.

\section{EU and Serbian policy and targets for energy efficiency}

Knoop \& Lechtenböhmer (2017) give a review of studies on energy efficiency potentials in the EU countries by 2030 . Using different scenarios, they analysed the EU national energy efficiency potentials countries envisaged for 2030. DeLlanoPaz, Fernandez \& Soares (2016) analysed the 2030 EU policy economic and environmental objectives through the Markowitz portfolio theory application. Markandya, Pedroso-Galinato \& Streimikiene (2006) showed that transition countries converge to EU countries due to energy intensity. Bertoldi \& Mosconi (2020) presented an econometric model for energy saving estimation inducing energy efficiency policies in the EU. They found that energy efficiency leads to a decrease in energy consumption in EU countries.

The Europe 2020 strategy (European Commission, 2010) has set a goal in terms of energy to be achieved by 2020 , including: improving energy efficiency by $20 \%$, increased share of renewable energy sources in final energy consumption to $20 \%$ and decrease in greenhouse gas emissions by $20 \%$ compared to 1990 . Also, the 2030 Framework for Climate and Energy (European Commission, 2020) was adopted, which set targets to be achieved by 2030: at least a $40 \%$ reduction in greenhouse gas emissions compared to 1990 levels, at least $32 \%$ share of renewable energy and at least $32.5 \%$ energy efficiency improvement. Specifically, it means that final energy consumption is 956 Mtoe and/or primary energy consumption of 1,273 Mtoe. Directives were set for different sectors and products in order to meet the set targets. According to Eurostat (2020), the primary energy consumption in 2018 reached 1376 Mtoe, $0.71 \%$ less than in 2017. Final energy consumption reached 990 Mtoe, $0.02 \%$ more than in 2017 . These results show that primary energy consumption is $4.9 \%$ above EU 2020 targets and $22 \%$ away from EU 2030 targets. The final energy consumption had a peak in 2006 (1046 Mtoe), and the lowest level in 2014 (937.5 Mtoe). In 2018, the final energy consumption was 3.2\% above EU 2020 targets and 17\% away from the EU 2030 targets.

Serbia, as the EU candidate country and the member of European Energy Community, has the obligation to fulfil EU energy treaty and other EU Directives in energy sector (Jednak et al., 2009). Therefore, some regulations are established due to conditions to energy efficiency improvement: The Energy law (2004), Law on Efficient Use of Energy (2013), the National Action Plan for energy efficiency (2010) and Energy Sector Development Strategy of the Republic of Serbia for the 
period until 2025 with projections to 2030 (2015). In line with Energy Community Treaty and national regulations, Serbia should decrease final energy consumption, increase the share of renewable energy, obtain GHG emission reductions, and increase energy efficiency. Serbia has to achieve EU Strategy 2030 targets by setting its own national energy efficiency targets as final energy consumption, primary or final saving, or energy intensity. The first National Action Plan for Energy Efficiency of the Republic of Serbia for the period (2010-2012) set indicative targets for reducing final energy consumption by $9 \%$, compared to the level of final energy consumption from the beginning of 2008 to the end of 2018 or 0.7524 Mtoe. According to the third Action Plan for Energy Efficiency of the Republic of Serbia for the period until 2018 (2017) at the end of 2015, about 50\% of energy saving is achieved as a set target. Also, the energy saving target was set as a decline in energy consumption by 0.3824 Mtoe till 2018 or $4.6 \%$ savings compared to 2008. According to Eurostat, primary energy consumption in 2008 was 15.9 Mtoe and in 2018 it was 14.8 Mtoe. Final energy consumption in 2008 was 9.5 Mtoe and in 2018 it was 9.0 Mtoe. The lowest energy consumption was in 2014 - 7.9 Mtoe. In both cases, energy consumption declined, but Serbia has a plan for its government to get more influence due to regulations to obtain energy efficiency.

\section{Economic and environmental benefits of energy efficiency improvements}

There is a range of economic, environmental, social and energy outcomes of the improved energy efficiency. Those benefits include: affordable energy and its access, social development and enhanced well-being and health. On economic level, i.e. localisation, benefits are on individual, sectoral, national, and economywide levels. Health and well-being, poverty reduction and disposable income raise are on the individual level (personal, household, and company level). Productivity of industry, competitiveness, energy provision, improved asset values and reduced environmental pollution are sectoral benefits. On the national level there are the following benefits: job creation, reduction of energy-related public expenditure, energy security, and macroeconomic effects (GDP and employment increase). Energy security, development goals (economic development, competitiveness, income rise, job creation, moderate energy prices, natural resource management, GHG emission mitigation and poverty alleviation are economy-wide benefits (Ryan \& Campbell, 2012). The improvement of energy efficiency brings forth multiple benefits, and it is a cost-effective activity. In order to obtain benefits from energy efficiency, governments provide various institutional, regional, fiscal and financial incentives (Marković et al., 2013). Besides benefits (desired outcomes), the improvement of energy efficiency causes direct and indirect rebound effects (undesired outcomes). 
A review of the influence of energy efficiency improvement on GDP, employment and $\mathrm{CO}_{2}$ emission will be given here. Investments in energy efficiency lead economic structure to less energy-intensive activities and more labourintensive activities. Furthermore, the implementation of energy efficiency measure in buildings improve investments in goods and services. Those investments are a component of GDP (Stanišić, 2018). Investments and decrease in energy demand both influence the increase in GDP (Holmes \& Mohanty, 2012; Stanišić, 2017). Energy efficiency increase will reduce energy bills, cut energy prices and costs, and increase the production (Barker et al., 2007). Improved energy efficiency with energy demand reduction by 8 to $15 \%$ has a potential impact on GDP increases from $0.8 \%$ to $1.26 \%$ (Ryan \& Campbell, 2012).

Investments in energy efficiency programs can create jobs both directly and indirectly. Directly - the creation of jobs while the energy efficiency project is being carried out. Indirectly - through consumer surplus spending, i.e. the euros saved from lower energy bills are spent on the economy (Bell, 2014). Indirect job creation refers to the jobs associated with the supply chain specific project. The effectiveness of creating jobs by energy efficiency program depends on size and structure of financing and type of energy saving. According to Wade et al. (2000), 26.6 jobs are created for every $€ 1$ million spent in an energy efficiency action. According to Bell (2014), energy efficiency supports 20.3 jobs per $\$ 1$ million in investments. Energy efficiency measures along with 30 renewable portfolio standards could bring over 4 million full-time jobs by 2030 (Wei et al., 2010). Janssen \& Staniaszek (2012) show that investing $€ 1$ million in enhancing building stock energy efficiency will make 19 new direct jobs in the sectors of construction. Investments in energy efficiency projects influence the rise of both GDP and employment.

Energy efficiency improvements positively affect the environment due to energy demand reduction and drop in fossil fuel consumption that results in reduced GHG emission (Holmes \& Mohanty, 2012). Energy efficiency improvement in industry results in the reduction of $\mathrm{CO}_{2}$ emission (Sathitbun-anan et al., 2014; Joelsson, 2008).

\section{Relationship between energy efficiency and economic and environmental indictors}

\subsection{Relationship between energy efficiency and GDP and employment}

In transition and emerging countries, a high economic growth rate can be achieved by the energy-intensive industry and infrastructure. However, this growth is followed by large energy consumption and environmental pollution (Zhao \& Zhao, 2019). Due to negative effects, energy efficiency should be applied in order to 
bring economic benefits and increase of GDP and employment. According to IEA (2019) energy efficiency has the potential to boost economic growth.

There is a connection between energy efficiency and GDP in the sense that improving energy efficiency leads to GDP increase (Kaufmann, 2004; GvozdenacUrošević, 2010; Chang \& Shieh, 2017). Hartwig, Kockat, Schade \& Braungardt (2017) use bottom-up modelling and input-output based model to present positive effects of energy efficiency policy on the GDP and employment. The Econometrics study (2015) assesses the linkage between energy efficiency and employment across Europe. Also, in this research, a CGE model and a macro-econometric model are used to estimate how the EU energy efficiency target would have an impact on GDP. Deichmann, Reuter, Vollmer \& Zhang (2018) show the relation between energy intensity and economic growth, applying a flexible piecewise linear regression model. The results suggest the rapid decrease of energy intensity as poor countries achieve economic growth, but when income rises, it is vital to sustain the rate of reduction in energy intensity.

Figures $3 \mathrm{a}$ and $3 \mathrm{~b}$ present the relationship between energy intensity and real GDP per capita growth in EU27 and Serbia for the period 2000-2018. This indicator is available only from 2000. Due to this fact, the observed period is shorter.

Figure 3a Energy intensity and real GDP per capita growth in EU27, 2000-2018

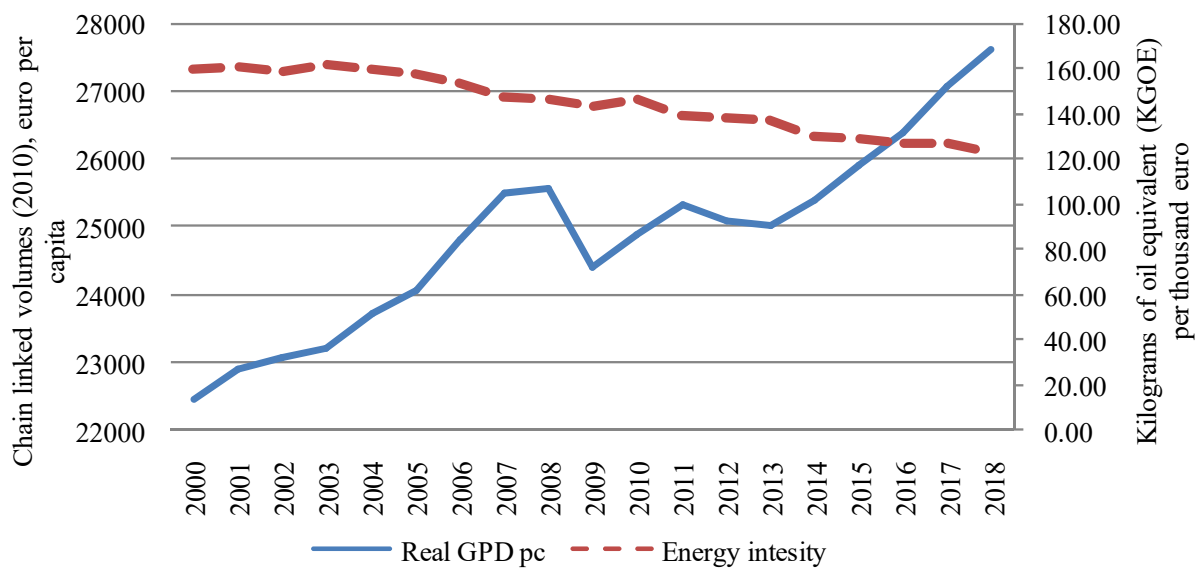

Source: Authors based on Eurostat data

In both EU27 and Serbia, we can see a negative relationship between real GDP per capita and energy intensity. 
Figure 3b. Energy intensity and real GDP per capita growth in Serbia, 2000-2018

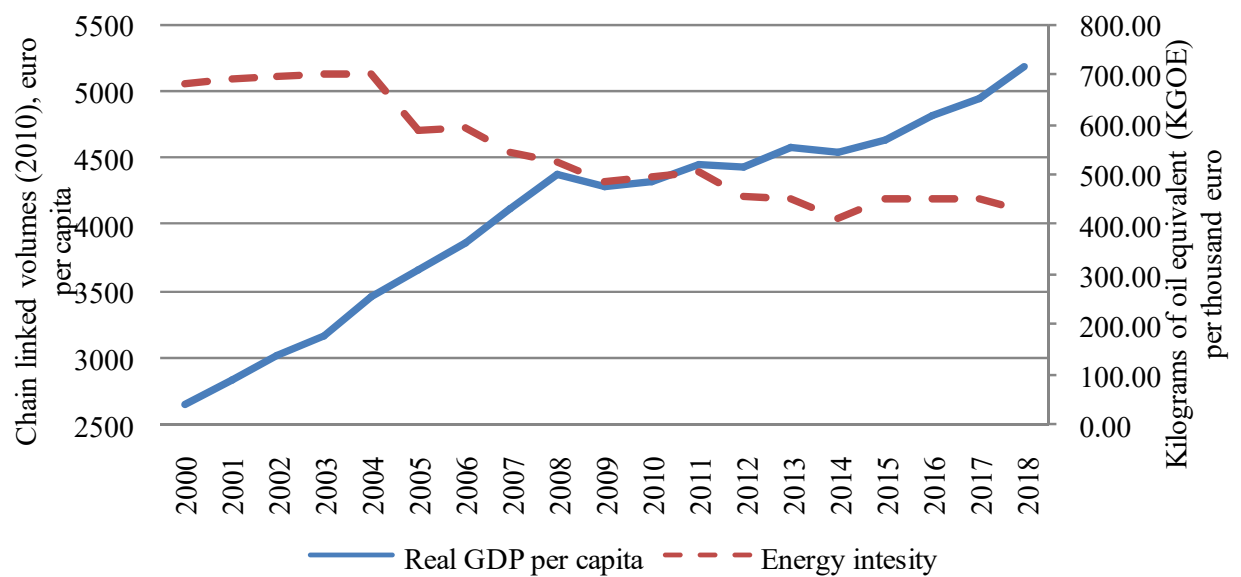

Source: Authors based on Eurostat data

\subsection{Relationship between energy efficiency and GHG emission}

The use of non-renewable sources of energy has an impact on the environment pollution and indirect impact on public health. Moving toward renewable resources enhances sustainable development and social well-being (Saad \& Taleb, 2018). Herring (2006) shows that a more effective $\mathrm{CO}_{2}$ policy means switching to nonfossil fuels, like renewable and limit energy consumption. According to Siitonen et al. (2009), the improvement of energy efficiency is the most promising measure for decrease of global $\mathrm{CO}_{2}$ emission. $\mathrm{CO}_{2}$ emission brings down ( $\mathrm{Su} \& \mathrm{Ang}, 2012$; Zhang, Ren, Zhou, Yu \& Chen, 2018) along with energy efficiency. In Serbia, about $76 \%$ of all GHG emissions come from the energy sector.

Figures $5 \mathrm{a}$ and $5 \mathrm{~b}$ present the relationship between energy intensity and greenhouse gas emission in EU27 and Serbia for the period 2000-2017. This indicator is available only from 2000 , due to this fact, the observed period is shorter.

Prior to testing the correlation among the selected variables, the variables' values are transformed into their natural logarithm form. This data transformation into their natural logarithm is to ensure that the results are efficient, reliable and consistent (Ali et al., 2019). A similar correlation analysis was used in Stošić and Minović (2014), but with different variables. 
Figure 5a. Energy intensity and greenhouse gas emission in EU27, 2000-2017

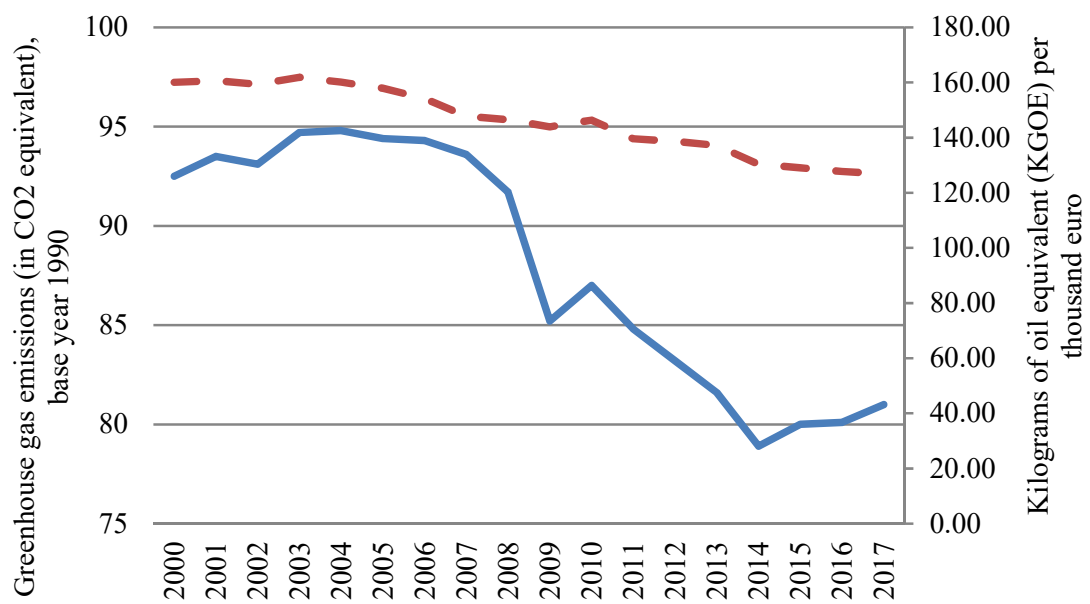

Greenhouse gas emissions - Energy intensity

Source: Authors based on Eurostat data

Figure 5b. Energy intensity and CO2 emission in Serbia, 2000-2018

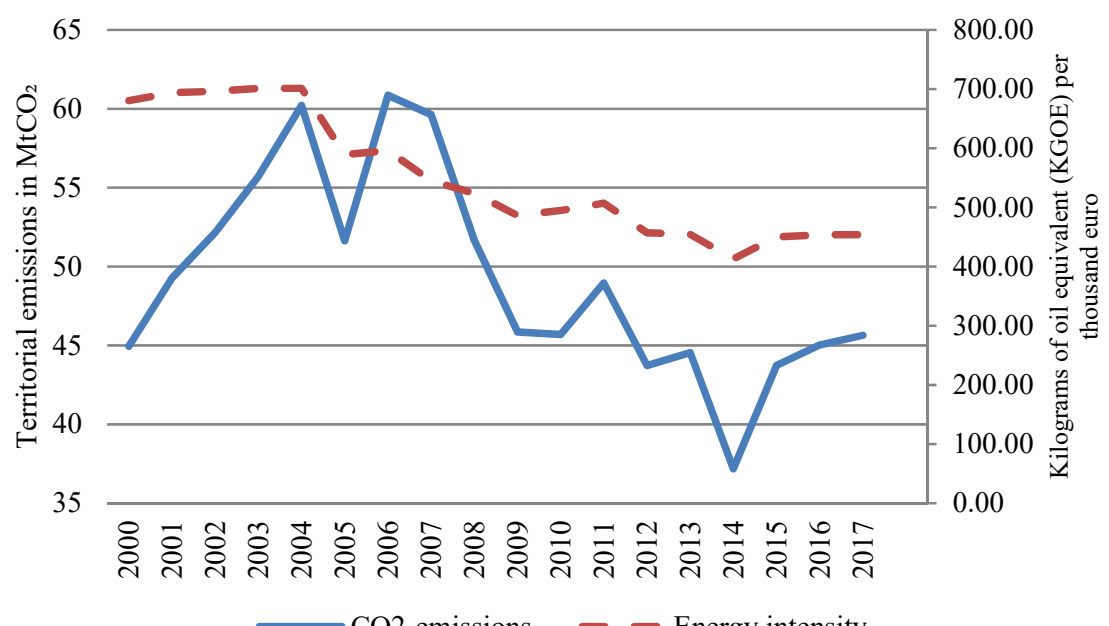

Source: Authors based on data from Eurostat and Global Carbon Atlas

The correlation coefficient among energy intensity, GDP, and GHG emission is calculated for EU27 (Table 2). The results show that there is a negative statistical significance at $1 \%$ level the correlation coefficient $(-0.881)$ between GDP and 
energy intensity. Then, there is a high and positive statistical significance at $1 \%$ level the correlation coefficient (0.947) between greenhouse gas emission growth and energy intensity. Finally, there is a negative statistical significance at $1 \%$ level the correlation coefficient $(-0.700)$ between greenhouse gas emission growth and GDP. These results are similar in some part of the research of Liobikiene \& Mandravickaitè (2016).

Table 2. The correlation coefficient for EU27 in the period 2000-2018

\begin{tabular}{c|rrr}
\hline \hline Correlation & EI & GDP & GHG \\
\hline \multirow{2}{*}{ EI } & 1.000 & & \\
& & & \\
& -0.881 & 1.000 & \\
& {$[-7.465]$} & & 1.000 \\
GHG & $(0.000)$ & & \\
& 0.947 & -0.700 & \\
& {$[11.747]$} & {$[-3.916]$} & \\
& $(0.000)$ & $(0.001)$ & \\
\hline \hline
\end{tabular}

Note: The value of t-statistics is in square brackets. The number in parentheses denotes $\mathrm{p}$ value. EI-energy intensity; GDP-gross domestic product; GHG-greenhouse gas emission.

Source: Authors' calculation.

Table 3. The correlation coefficient for Serbia in the period 2000-2018

\begin{tabular}{c|rrr}
\hline \hline Correlation & EI & GDP & $\mathrm{CO}_{2}$ \\
\hline \multirow{3}{*}{ GDP } & 1.000 & & \\
& & & \\
& -0.929 & 1.000 & \\
$\mathrm{CO}_{2}$ & {$[-10.384]$} & & 1.000 \\
& $(0.000)$ & & \\
& 0.683 & -0.400 & \\
& {$[3.856]$} & {$[-1.797]$} & $(0.090)$ \\
\hline \hline
\end{tabular}

Note: The value of t-statistics is in square brackets. The number in parentheses denotes $\mathrm{p}$ value. EI-energy intensity; GDP-gross domestic product; $\mathrm{CO}_{2}-\mathrm{CO}_{2}$ emission.

Source: Authors' calculation. 
The correlation coefficient among energy intensity, GDP, and $\mathrm{CO}_{2}$ emission is calculated for Serbia (Table 3). The results show that there is a negative statistical significance at $1 \%$ level the correlation coefficient $(-0.929)$ between GDP and energy intensity. Then, there is a positive statistical significance at $1 \%$ level the correlation coefficient $(0.683)$ between $\mathrm{CO}_{2}$ and energy intensity, and negative statistical significance at $10 \%$ level the correlation coefficient $(-0.400)$ between $\mathrm{CO}_{2}$ and GDP. These results are similar in some part of the researches of Liobikienè \& Mandravickaite (2016) and Gvozdenac-Urošević (2010).

\section{Conclusion}

Energy efficiency emerged as an issue starting with the oil crisis, and it gained importance with sustainable development. As an integral part of sustainable development, it promotes energy efficiency as a target, in order to give a range of economic, environmental and energy benefits. This paper provides a theoretical review of energy efficiency trends in EU27 and Serbia. In the observed countries, there is an increase in energy efficiency. The policy and strategy are coherent because Serbia, as an EU candidate country, should fulfil the EU policy. However, Serbia lags behind EU27 due to poor results in energy efficiency. Furthermore, the paper shows the relationship between energy efficiency and GDP and GHG emission. The results show that, along with energy intensity decline, there is a GDP rise and GHG emission decrease both in EU27 and Serbia. The available data were limited, so the indicators were analysed for a shorter period of time. This paper is an introduction to future research. The next research will be dedicated to causality among energy consumption, renewable energy, income and GHG emission.

\section{References}

Ali, S., Ying, L., Shah, T., Tariq, A., Ali Chandio, A., \& Ali, I. (2019). Analysis of the Nexus of $\mathrm{CO}_{2}$ Emissions, Economic Growth, Land under Cereal Crops and Agriculture ValueAdded in Pakistan Using an ARDL Approach. Energies, 12(23), 4590.

Barker, T., Ekins, P., \& Foxon, T. (2007). The macro-economic rebound effect and the UK economy. Energy Policy, 35(10), 4935-4946.

Bell, C. J. (2014). Understanding the true benefits of both energy efficiency and job creation. Community Development Investment Review, 10(1), 109-116.

Bertoldi, P., \& Mosconi, R. (2020). Do energy efficiency policies save energy? A new approach based on energy policy indicators (in the EU Member States). Energy Policy, 139, 111-320.

Chang, M. C., \& Shieh, H. S. (2017). The Relations Between Energy Efficiency And GDP In The Baltic Sea Region And Non-Baltic Sea Region. Transformations in Business \& Economics, $16(2)$.

Cornillie, J., \& Fankhauser, S. (2004). The energy intensity of transition countries. Energy Economics, 26(3), 283-295.

Deichmann, U., Reuter, A., Vollmer, S., \& Zhang, F. (2018). Relationship between energy intensity and economic growth: new evidence from a multi-country multi-sector data set. The World Bank. 
deLlano-Paz, F., Fernandez, P. M., \& Soares, I. (2016). Addressing 2030 EU policy framework for energy and climate: Cost, risk and energy security issues. Energy, 115, 1347-1360.

Econometrics, C. (2015). Assessing the employment and social impact of energy efficiency. Cambridge Econometrics.

EEA -European Environment Agency (2019). Progress on energy efficiency in Europe. Indicator Assessment. European Environment Agency Retrieved from $\mathrm{https}$ ://www.eea.europa.eu/data-and-maps/indicators/progress-on-energy-efficiency-ineurope-3/assessment

European Commission (2020). 2030 climate and energy framework. Energy, Climate change, Environment. Dostupno na https://ec.europa.eu/clima/policies/strategies/2030_en

European Commission (EC). (2010). EUROPE 2020: A strategy for smart, sustainable and inclusive growth. Working paper \{COM (2010) 2020\}.

European Parliament (2015). Understanding energy efficiency. Briefing.October 2015

Eurostat (2020). Energy consumption in 2018. Eurostat newsrelease. Retrieved from https://ec.europa.eu/eurostat/documents/2995521/10341545/8-04022020-BPEN.pdf/39dcc365-bdaa-e6f6-046d-1b4d241392ad

Fawcett, T., \& Killip, G. (2019). Re-thinking energy efficiency in European policy: Practitioners' use of 'multiple benefits' arguments. Journal of cleaner production, 210, 1171-1179.

Gillingham, K., Rapson, D., \& Wagner, G. (2016). The rebound effect and energy efficiency policy. Review of Environmental Economics and Policy, 10(1), 68-88.

Goldemberg, J. (2020). The evolution of the energy and carbon intensities of developing countries. Energy Policy, 137, 111060.

Gvozdenac-Urošević, B. (2010). Energy efficiency and GDP. Thermal Science, 14(3), 799-808.

Hartwig, J., Kockat, J., Schade, W., \& Braungardt, S. (2017). The macroeconomic effects of ambitious energy efficiency policy in Germany - Combining bottom-up energy modeling with a non-equilibrium macroeconomic model. Energy, 124, 510-520.

Herring, H. (2006). Energy efficiency — a critical view. Energy, 31(1), 10-20.

Holmes, I., \& Mohanty, R. (2012). The Macroeconomic Benefits of Energy Efficiency. Third Generation Environmentalism Ltd (E3G), London, UK.

IEA (2019). Energy efficiency 2019 - The authoritative tracker of global energy efficiency trends. Report. November 2019 Retrieved from https://www.iea.org/reports/energy-efficiency2019

IEA. (2019a). Multiple benefits of Energy Efficiency: from "hidden fuel" to "first fuel". IEA, Paris, 2019. Retrieved from https://www.iea.org/reports/multiple-benefits-of-energyefficiency (accessed on 9.5.2020).

Janssen, R., \& Staniaszek, D. (2012). How Many Jobs? A survey of the employment effects of investment in Energy Efficiency of Buildings. In The Energy Efficiency Industrial Forum.

Jednak, S., Kragulj, D., Bulajic, M., \& Pittman, R. (2009). Electricity reform in Serbia. Utilities Policy, 17(1), 125-133.

Joelsson, A. (2008). Primary energy efficiency and CO2 mitigation in residential buildings (Doctoral dissertation, Mid Sweden University).

Kaufmann, R. K. (2004). The mechanisms for autonomous energy efficiency increases: A cointegration analysis of the US energy/GDP ratio. The Energy Journal, 25(1).

Kerr, N., Gouldson, A., \& Barrett, J. (2017). The rationale for energy efficiency policy: Assessing the recognition of the multiple benefits of energy efficiency retrofit policy. Energy Policy, $106,212-221$.

Knoop, K., \& Lechtenböhmer, S. (2017). The potential for energy efficiency in the EU Member States - A comparison of studies. Renewable and Sustainable Energy Reviews, 68, 10971105 . 
Krstić, J., Reljić, M., \& Filipović, S. (2018). Factors influencing electricity consumption: a review of research methods. Management: Journal of Sustainable Business and Management Solutions in Emerging Economies, 24(2), 13-22.

Liobikienè, G., \& Mandravickaite, J. (2016). The EU Cohesion Policy implications to GHG emissions from production-based perspective. Environmental Science \& Policy, 55, 178185.

Malinauskaite, J., Jouhara, H., Ahmad, L., Milani, M., Montorsi, L., \& Venturelli, M. (2019). Energy efficiency in industry: EU and national policies in Italy and the UK. Energy, 172, 255-269.

Markandya, A., Pedroso-Galinato, S., \& Streimikiene, D. (2006). Energy intensity in transition economies: is there convergence towards the EU average?. Energy Economics, 28(1), 121145.

Marković, D., Furtula, S., \& Jovković, B. (2013). Finansijski podsticaji energetskoj efikasnosti u državama EU i Srbiji. Ekonomske teme, 51(3), 561-578.

Nagesha, N., \& Subrahmanya, M. B. (2006). Energy efficiency for sustainable development of small industry clusters: what factors influence it?. International Journal of Economic Policy Studies, 1(1), 133-153.

Petrović, P., Filipović, S., \& Radovanović, M. (2018). Underlying causal factors of the European Union energy intensity: Econometric evidence. Renewable and Sustainable Energy Reviews, 89, 216-227.

Reddy, B. S., \& Ray, B. K. (2010). Decomposition of energy consumption and energy intensity in Indian manufacturing industries. Energy for Sustainable Development, 14(1), 35-47.

Rosenow, J., \& Bayer, E. (2017). Costs and benefits of energy efficiency obligations: a review of European programmes. Energy Policy, 107, 53-62.

Ryan, L., \& Campbell, N. (2012). Spreading the net: the multiple benefits of energy efficiency improvements. OECD.

Ryan, L., \& Campbell, N. (2012). Spreading the net: the multiple benefits of energy efficiency improvements.

Saad, W., \& Taleb, A. (2018). The causal relationship between renewable energy consumption and economic growth: evidence from Europe. Clean Technologies and Environmental Policy, 20(1), 127-136.

Sadorsky, P. (2013). Do urbanization and industrialization affect energy intensity in developing countries?. Energy Economics, 37, 52-59.

Safarzadeh, S., \& Rasti-Barzoki, M. (2019). A game theoretic approach for assessing residential energy-efficiency program considering rebound, consumer behavior, and government policies. Applied energy, 233, 44-61.

Sathitbun-anan, S., Fungtammasan, B., Barz, M., Sajjakulnukit, B., \& Pathumsawad, S. (2014). Energy efficiency and greenhouse gas emission reduction potentials in sugar production processes in Thailand. Energy for Sustainable Development, 23, 266-274.

Siitonen, S., Tuomaala, M., Suominen, M., \& Ahtila, P. (2010). Implications of process energy efficiency improvements for primary energy consumption and $\mathrm{CO} 2$ emissions at the national level. Applied Energy, 87(9), 2928-2937.

Sorrell, S. (2015). Reducing energy demand: A review of issues, challenges and approaches. Renewable and Sustainable Energy Reviews, 47, 74-82.

Stanišić N. (2018). Makroekonomske koristi od unapređenja energetske efikasnosti u stambenim zgradama $u$ Srbiji. GIZ

Stanišić N. (2018). Study on the Macroeconomic Impacts of Energy Efficiency Measures in Schools and Kindergartens in Serbia. GIZ

Stošić, I., \& Minović, J. (2014). Benchmarking western Balkan economies. Industrija, 42(1), 149170. 
Su, B., \& Ang, B. W. (2012). Structural decomposition analysis applied to energy and emissions: some methodological developments. Energy Economics, 34(1), 177-188.

The third Action Plan for Energy Efficiency of the Republic of Serbia for the period until 2018 (2017). Official Gazette of RS", No. 1/17 of January 6, 2017.

Tracking Report (2019). Tracking Industry. IEA https://www.iea.org/reports/tracking-industry2019

Trianni, A., Cagno, E., \& Farné, S. (2016). Barriers, drivers and decision-making process for industrial energy efficiency: A broad study among manufacturing small and medium-sized enterprises. Applied Energy, 162, 1537-1551.

Wade, J., Wiltshire, V., \& Crase, I. (2000). National and local employment impacts of energy efficiency investment programmes. Final report to the European Commission, 1.

Wei, M., Patadia, S., \& Kammen, D. M. (2010). Putting renewables and energy efficiency to work: How many jobs can the clean energy industry generate in the US?. Energy policy, 38(2), 919-931.

Zhang, S., Ren, H., Zhou, W., Yu, Y., \& Chen, C. (2018). Assessing air pollution abatement cobenefits of energy efficiency improvement in cement industry: A city level analysis. Journal of Cleaner Production, 185, 761-771.

Zhao, H., Guo, S., \& Zhao, H. (2019). Provincial energy efficiency of China quantified by threestage data envelopment analysis. Energy, 166, 96-107.

Zweifel, P., Praktiknjo, A., \& Erdmann, G. (2017). Energy economics: theory and applications. Springer.

\section{PREGLED EKONOMSKIH INDIKATORA I INDIKATORA ŽIVOTNE SREDINE I ENERGETSKE EFIKASNOSTI: PRIKAZ EU I SRBIJE}

Apstrakt: Energija je globalno važan faktor proizvodnje. Rast stanovništva i dohotka povećavaju potrošnju energije, ali isto tako postoji potreba za smanjenjem potrošnje. Postoje različiti načini da se potrošnja energije smanji, a jedan od njih je i energetska efikasnost. Cilj rada je da se predstavi teorijski pregled energetske efikasnosti i njenih prednosti. Svrha rada je analiza indikatora ekonomije i životne sredine i energetske efikasnosti u EU27 (posle 2020.) i Srbiji. Prikazani su trendovi energetske efikasnosti, BDP po glavi stanovnika i GHG emisije u posmatranim zemljama. Predstavljene su evropska i srpska politika, ciljevi energetske efikasnosti, kao i to da li su oni i na kom nivou zemlje ostvareni. Da bi se uvidela povezanost između energetske efikasnosti, BDP-a po glavi stanovnika i GHG emisije, primenjena je korelacija svih varijabli. Rezultati pokazuju da je energetska efikasnost u EU27 veća nego u Srbiji. Iako Srbija ima povećanje energetske efikasnosti u posmatranom periodu (1995-2018), ona zaostaje za EU27. U EU27 i Srbiji postoji pozitivna korelacija između energetske efikasnosti i BDP-a i GHG emisije.

Ključne reči: energetska efikasnost, energetska intezivnost, BDP, energija, GHG emisija, Evropska unija, Srbija 


\section{Authors' biographies}

Sandra Jednak, PhD, is employed at the Faculty of Organizational Sciences, University of Belgrade as an Associate Professor. She has published scientific research papers in international and national monographs, journals and conferences proceedings. Her teaching areas are an introduction to economics, macroeconomics, microeconomics, economic development and EU. Her research focus is on economic development, energy economics, knowledge economy, international economics and higher education.

Jelena Minović, $\mathrm{PhD}$, is Senior Research Associate at the Institute of Economic Sciences in Belgrade. She is a member of the Scientific Society of Economists in Serbia. Jelena participated in many international and national conferences. She published a significant number of papers (about 90). Her research interests are Quantitative Methods and Models in Finance and Economics, Econometrics, Time Series Analysis, Financial Economics, Financial Markets, Theory of Economic Growth, and Foreign Direct Investments. Her articles have been published in various international journals.

Dragana Kragulj, $\mathrm{PhD}$, is a Full Professor of Economics at Faculty of Organizational Sciences at University of Belgrade. She graduated from the Faculty of Economics, University of Belgrade, where she also got her MSc degree and $\mathrm{PhD}$ degree. She was a Head of Department of Economics, Business Planning and International Management. Also, she was a Head of Center for Economic and Business Research. She has published two monographs, several editions of different textbooks of Economics and over 100 peer-reviewed papers. The areas of her research interest include macroeconomic problems, prices, market, inflation, economic development, investment, agriculture, energy economics, process of transition, international economic integrations, the European Union. 